\title{
Microwave-Assisted Convenient Syntheses of 2-Indolizine Derivatives from Morita-Baylis-Hillman Adducts: New in silico Potential Ion Channel Modulators
}

\author{
Saraghina M. D. Cunha, Ramon G. de Oliveira and Mário L. A. A. Vasconcellos* \\ Departamento de Química, Universidade Federal da Paraíba, Campus I, \\ 58059-900 João Pessoa-PB, Brazil
}

\begin{abstract}
Neste artigo, um estudo sintético assistido por irradiação de micro-ondas para produzir 2-indolizina-carbonitrila e 2-indolizina-carboxilato de metila em bons a altos rendimentos (70 e $81 \%$ ) em uma etapa a partir de adutos de Morita-Baylis-Hillman (AMBH) é apresentado. Estes compostos foram subsequentemente transformados em altos rendimentos (94-100\%) em três derivados 2-indolizínicos. Os cinco compostos sintetizados foram idealizados in silico objetivando potenciais atividades seletivas como moduladores de canais iônicos. Estas atividades foram sugeridas pelos valores de pontuação usando o programa quimioinformático Molinspiration.
\end{abstract}

In this work, a microwave-assisted synthesis study by microwave irradiation to produce indolizine-2-carbonitrile and indolizine-2-carboxylate in good to high yields (70 and 81\%, respectively) in one step from Morita-Baylis-Hillman adducts (MBHA) is presented. These compounds were subsequently transformed to high yields (94 to $100 \%$, respectively) in three 2 -indolizine derivatives. The five synthesized compounds were designed in silico aiming to present potential selective activities as ion channel modulators. These activities were suggested by the score values using Molinspiration Cheminformatics program.

Keywords: Morita-Baylis-Hillman adducts, 2-indolizine derivatives, microwave, potential ion channel modulators, Molinspiration Cheminformatics program

\section{Introduction}

Indolizines constitute a class of heteroaromatic compounds containing two condensed rings (5 and 6-membered) and a bridging nitrogen atom. This structural moiety (Figure 1) is found in natural products and has been used as an essential skeleton in pharmaceutics. Efficient and versatile synthetic methods for producing indolizine derivatives have been actively investigated. ${ }^{1}$ Some compounds presenting indolizine moiety have been reported as L-type calcium channel blockers, ${ }^{2}$ leukotriene synthesis inhibitors, ${ }^{3}$ histamine $\mathrm{H}_{3}$ receptor antagonists, ${ }^{4}$ $5-\mathrm{HT}_{1 \mathrm{~A}}$ receptor ligands $\mathrm{s}^{5}$ and phosphodiesterase $\mathrm{V}$ inhibitors. ${ }^{6}$ The biological diversity of indolizine derivatives was realized just before the start of this century and has been recently revised.?

Among these various classes of bioactivities, ${ }^{7}$ it is noteworthy the significant number of indolizine derivatives (Figure 2) acting as ion channel modulators. ${ }^{8,9}$

*e-mail:mlaav@quimica.ufpb.br

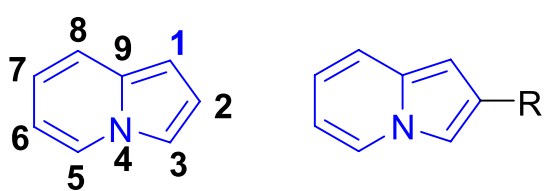

Figure 1. Structure and numbering system of indolizine, and a general 2-indolizine moiety.

Even if efficient synthetic methods for producing indolizine derivatives have been continuously investigated, ${ }^{1}$ many synthetic methods require an organized pyridine derivative with functionalized alkynyl or homoalkynyl groups on the 2-position. ${ }^{10}$ Therefore, the investigation of an alternative method having various functional group variations on the indolizine nucleus is highly desirable for biological activity studies.

Curiously, according to our knowledge, it is not described in literature efficient 2-indolizines derivative syntheses. For example, the best indolizine-2-carbonitrile synthesis (1, Figure 3) was described by Kaye and Bode ${ }^{11}$ using thermal cyclisation condition in three steps from 2-pyridyl derivative on $32 \%$ yield. 
<smiles>N#Cc1ccn2c(-c3ccccc3)c(-c3ccccc3)c(O)c2c1</smiles><smiles>N#Cc1ccn2c(-c3ccccc3)c(-c3ccccc3)c(CO)c2c1</smiles><smiles>COC(=O)c1c(-c2ccccc2)c(-c2ccccc2)n2ccc(C#N)cc12</smiles><smiles>COc1ccc(CCN(C)CCCOc2ccc(S(=O)(=O)c3c(C(C)C)cn4ccccc34)cc2)cc1OC</smiles>

SR 33557 (fantofanme) L-type calcium channel blocker<smiles>O=C(N[C@H]1CN2CCC1CC2)c1ccn2cccc2c1</smiles><smiles>CCc1cn2c(Cc3ccccc3)ccc(OCC(=O)O)c2c1CC(N)=O</smiles><smiles>C=CCCCCC(C)c1cc2ccccn2c1S(=O)(=O)c1ccc(OCCCN(CCCC)CCCC)cc1</smiles>

Figure 2. Some ion channel blockers based on indolizine moiety (in blue). ${ }^{8}$<smiles>N#Cc1cc2ccccn2c1</smiles>

1<smiles>COC(=O)c1cc2ccccn2c1</smiles>

2<smiles>O=C(O)c1cc2ccccn2c1</smiles>

3<smiles>NCc1cc2ccccn2c1</smiles>

4<smiles>OCc1cc2ccccn2c1</smiles>

5

Figure 3. Selected structures to be synthesized in this work.

In a recent work, ${ }^{12}$ our group described microwave-assisted syntheses of new monoacylglycerols (MAGs) from MoritaBaylis-Hillman reaction (MBHR, Scheme 1). MBHR occurs between an $\mathrm{sp}^{2}$ electrophilic carbon (i.e., aldehydes, ketones) and the $\alpha$ position of an alkene connected to an electron-attractor group (EAG), under a tertiary amine as nucleophilic catalysis, being 1,4-diazabicyclo[2.2.2]octane (DABCO) widely used catalyst (Scheme 1). ${ }^{13}$ It was also described in that article, ${ }^{12}$ a reaction between Morita-BaylisHillman adduct under microwave irradiation that produced a complex compound mixture, among them, the 2-indolizine (Scheme 2) in very low yields.

In connection with our interest in the new bioactive compound synthesis and microwave use on optimizing synthesis,${ }^{14}$ our group decided to investigate the microwave irradiation use on synthetic methodologies development

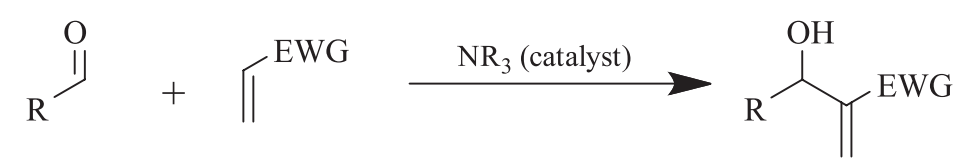<smiles>C1CN2CCN1C2</smiles>

$\mathrm{R}=$ alkyl, aryl, $\mathrm{H}$ $\mathrm{EWG}=\mathrm{CO}_{2} \mathrm{R}, \mathrm{CN}, \mathrm{COR}$, others

MBHA

Scheme 1. General scheme for Morita-Baylis-Hillman reactions. ${ }^{4}$ 


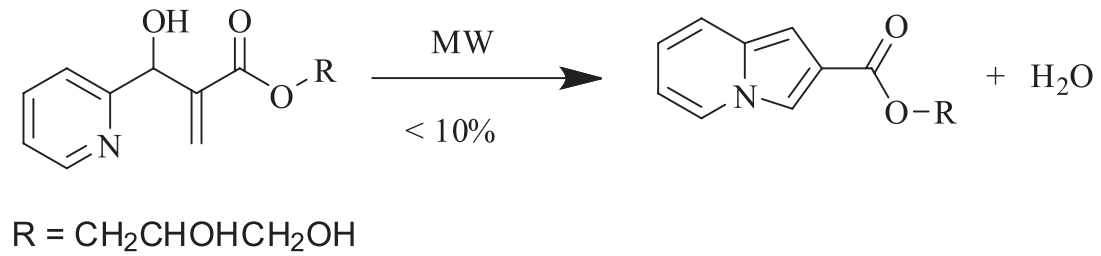

Scheme 2. Synthesis with very low yield of 2-indolizine derivative, characterized by CG-MS. ${ }^{12}$

to obtain new and known 2-indolizidine derivatives from MBHR. It was selected compounds that presented in silico potentiality as ionic channel modulator. ${ }^{8}$ The five structures synthesized in this work are shown in Figure 3. These compounds did not present up to now efficient syntheses described in the literature.

The compound selection shown in Figure 3 was based on in silico evaluation by using Molinspiration Cheminformatics program. ${ }^{15}$ The Molinspiration Cheminformatics program presents specific activity scores for each of these six receptor classes (GPCR ligand, ion channel modulator, kinase inhibitor, nuclear receptor ligand, protease inhibitor and enzyme inhibitor). Using this program, it is also possible to calculate the Lipinski's rule of five proprieties. ${ }^{16}$ Molinspiration Cheminformatics virtual screening methodology can efficiently separate drug-likeness from inactive structures. For example, alcohol 5 presents a score of +0.51 to ion channel modulator that are higher than the medium score drug on database program (Table 1). Similarly, structure $\mathbf{4}$ presents a score of +0.85 to ion channel modulator that is very higher than the medium score drug on the same database program (Table 1).

Table 1. Molinspiration Cheminformatics virtual screening results for compounds 1-5 and the medium score drug-like molecules on the database

\begin{tabular}{lccc}
\hline entry & Compound & L-R violations $^{\mathrm{b}}$ & ${\text { I.C.M. } \text { score }^{\mathrm{c}}}^{\mathrm{c}}$ \\
\hline 1 & indolizine & 0 & -0.65 \\
2 & $\mathbf{1}$ & 0 & +0.32 \\
3 & $\mathbf{2}$ & 0 & +0.39 \\
4 & $\mathbf{3}$ & 0 & +0.48 \\
5 & $\mathbf{4}$ & 0 & +0.85 \\
6 & $\mathbf{5}$ & 0 & +0.51 \\
7 & M.S.D. $^{\mathrm{a}}$ & - & +0.25 \\
\hline
\end{tabular}

${ }^{a}$ Medium score drug-like molecules on the Molinspiration Cheminformatics

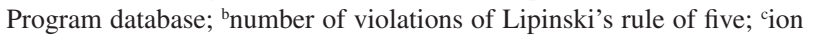
channel modulator score.

In this present work, the structures 1-5 were selected to be synthesized (Figure 2) after in silico investigating more than two hundred compounds presenting the privileged 2-indolizine structure. ${ }^{17}$ It was prioritized structures that presented high positive in silico score as ion channel modulators. It is worth noting the very high score value obtained for 4 (entry 5, Table 1), as well its selectivity as modulator of ionic channel.

Obviously this preliminary in silico approach must be experimentally validated, but it was considered the use of Molinspiration Cheminformatics program a good virtual screening methodology. Recently, some research groups used the Molinspiration Cheminformatics on rational approach in drug design. ${ }^{18}$

So, it is presented in this work our experimental results using microwave-accessing one-pot synthesis of indolizine2-carbonitrile (1) and methyl indolizine-2-carboxylate (2) from MBHA, as well it is described very efficient syntheses to the derivatives $\mathbf{3}, \mathbf{4}$ and $\mathbf{5}$ (Figure 3).

\section{Results and Discussion}

Our experimental work began on MBHA 6 synthesis (Scheme 3). Thus, reacting excess of methyl acrylate (reactant and solvent) with 2-pyridinecarboxaldehyde in the presence of 1 equiv. of DABCO as a promoter at $0{ }^{\circ} \mathrm{C}$ for $5 \mathrm{~h}$ produced quantitatively the pure adduct 6 .

The conditions and results on indolizine-2-carboxylate (2) synthesis are summarized in Table 2. Acidic dry amberlyst-15 resin use was inefficient comparing with wet amberlyst-15 in this transformation (entry 1 vesus 2 , Table 2). Curiously, resin-free conditions were more efficient in all examples (entries 1-2 versus 3-9). Considering the results presented in Table 2, with methanol concentration and irradiation time variation, it was determined that there is an ideal relationship of methanol $(0.5 \mathrm{~mL})$ to MBHA $6(1 \mathrm{mmol})$ under irradiation by $100 \mathrm{~min}$ at $100{ }^{\circ} \mathrm{C}$. Finally, differently than described, ${ }^{11}$ methyl indolizine-2-carboxylate (2) preparation was performed in high yields ( $80-81 \%$, entries 7 and 9, Table 2) under microwave irradiation at $100{ }^{\circ} \mathrm{C}$ using methanol as solvent. In fact, it was discovered a condition to produce the 2-indolizine 2 , which can be isolated with $100 \%$ purity (evaluated by CG-MS) after methanol evaporation.

In sequence, the ester 2 was reduced on 100\% yield by using $\mathrm{LiAlH}_{4}$ on dry tetrahydrofuran (THF), producing alcohol $\mathbf{5}$. The alcohol $\mathbf{5}$ synthesis was described in literature in $80 \%$ yield. ${ }^{19}$ 
<smiles>C=CC(=O)OC</smiles>

6 (ii)<smiles>COC(=O)c1cc2ccccn2c1</smiles>

2

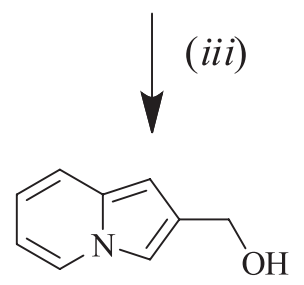

5

Scheme 3. (i) Methyl acrylate, 2-pyridinecarboxaldehyde, DABCO (1 equiv.), $0{ }^{\circ} \mathrm{C}, 30 \mathrm{~min}, 100 \%$; (ii) microwave irradiation, conditions in Table 2; (iii) $\mathrm{LiAlH}_{4}, 2$ on dry THF, $3 \mathrm{~h}, 0{ }^{\circ} \mathrm{C} \rightarrow$ room temperature, $100 \%$.

Table 2. Optimizing conditions to prepare indolizine-2-carboxylate (2)

\begin{tabular}{lccccc}
\hline entry & MBHA 6/mmol & Solvent / $\mathrm{mL}(\mathrm{MeOH})$ & Catalyst & time / min & Yields $/ \%$ \\
\hline 1 & 1.0 & 3.0 & amberlyst-15 wet & 20 & 51 \\
2 & 1.0 & 3.0 & amberlyst-15 dry & 20 & 17 \\
3 & 1.0 & 3.0 & - & 20 & 68 \\
4 & 1.0 & 3.0 & - & 60 & 55 \\
5 & 1.0 & 2.0 & - & 60 & 46 \\
6 & 1.0 & 2.0 & - & 60 & 55 \\
7 & 2.5 & 2.0 & - & 100 & 80 \\
8 & 3.0 & 2.0 & - & 100 & 70 \\
9 & 5.0 & & - & & 81 \\
\hline
\end{tabular}

asolated yields. The reactions were performed at $100^{\circ} \mathrm{C}$.

Acid 3 synthesis was done in accordance to that described procedure. ${ }^{20}$ So, 1 equiv. of ester 2 was reacted with a solution of 6 equiv. of $\mathrm{KOH}$ on refluxing ethanol by $16 \mathrm{~h}$, followed by conventional purification, providing the acid $\mathbf{3}$ in quantitative yield (Scheme 4).<smiles>COC(=O)c1cc2ccccn2c1</smiles>

2

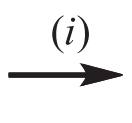<smiles>O=C(O)c1cc2ccccn2c1</smiles>

Scheme 4. (i) Ester 2 (3 mmol), $21 \mathrm{~mL}$ of $\mathrm{KOH}$ ethanolic solution $\left(1 \mathrm{~mol} \mathrm{~L}^{-1}\right), 16 \mathrm{~h}, 100{ }^{\circ} \mathrm{C}, 100 \%$ yield.

Scheme 5 presents the synthetic route for 1 and 4 compounds, from MBHA 7. The 7 synthesis was made in quantitative yield by reaction between 2-pyridinecarboxaldehyde and acrylonitrile assisted by microwave irradiation $\left(30 \mathrm{~min}, 80{ }^{\circ} \mathrm{C}\right)$ in a solvent-free condition, in the presence of 1 equiv. of DABCO. ${ }^{21}$ Pure 7 was obtained after a filtration through silica gel (Scheme 5).
In Table 3, our results are presented, optimizing indolizine-2-carbonitrile (1) synthesis.

As can be seen in entry 1 (Table 3 ), the amberlyst- 15 resin use was ineffective using acetonitrile as solvent. In fact, acetonitrile proved to be inefficient as solvent to this transformation, even at 90 min of microwave irradiation (entries 1, 2 and 3, Table 3). Using dimethylformamide (DMF) as solvent, a complex product mixture was obtained (entry 4). In a different way, the acetic anhydride use as solvent produces 1 in a moderate yield (entry 5). The yields obtained by using ethanol and methanol as solvents were different. Note that methanol use was unproductive and ethanol use resulted in $\mathbf{1}$ formation in the same yield as described in the literature (32\%, entry 5 and 6). ${ }^{11}$ Successfully, the TFE use as solvent improve significantly to the reaction yield (70\%, entry 8 ). Beside this, the TFE use facilitates the $\mathbf{1}$ purification that occurs by solvent evaporation. Increasing reaction concentration led to the decrease in the reaction yield (entries 9-10 versus 8). Scheme 6 presents the general mechanism proposed by 
<smiles>C=CC(C)C(C#N)C(O)c1cccnc1C(=C)C#N</smiles>

7<smiles>[Mg][Mg][Mg]</smiles>

Table 3<smiles>N#Cc1cc2ccccn2c1</smiles>

1

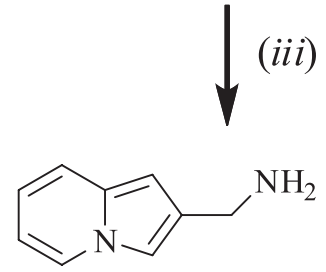

4

Scheme 5. Synthetic route for the preparation of compounds $\mathbf{1}$ and $\mathbf{4}$. (i) microwave irradiation, $80{ }^{\circ} \mathrm{C}, 30$ min, $100 \%$; (ii) microwave irradiation, conditions and results in Table 3; (iii) $\mathrm{LiAlH}_{4}, 2$ on dry THF, $2 \mathrm{~h}, 0{ }^{\circ} \mathrm{C}, 98.5 \%$.

Table 3. Synthetic studies to prepare indolizine-2-carbonitrile (1)

\begin{tabular}{|c|c|c|c|c|c|c|}
\hline entry & $\mathbf{1 1} / \mathrm{mmol}$ & Catalyst & Solvent (1 mL) & Temperature $/{ }^{\circ} \mathrm{C}$ & time / min & Yield $^{\mathrm{a}} / \%$ \\
\hline 1 & 1.0 & $200 \mathrm{mg}$ wet amberlyst- 15 & $\mathrm{MeCN}$ & 100 & 60 & 8 \\
\hline 2 & 1.0 & - & $\mathrm{MeCN}$ & 100 & 60 & 10 \\
\hline 3 & 1.0 & - & $\mathrm{MeCN}$ & 100 & 90 & 15 \\
\hline 4 & 1.0 & - & DMF & 100 & 60 & $<5^{b}$ \\
\hline 5 & 1.0 & - & $\mathrm{Ac}_{2} \mathrm{O}$ & 100 & 90 & 45 \\
\hline 6 & 1.0 & - & $\mathrm{MeOH}$ & 100 & 60 & $<5^{\mathrm{b}}$ \\
\hline 7 & 1.0 & - & EtOH & 100 & 60 & 32 \\
\hline 8 & 1.0 & - & $\mathrm{TFE}^{\mathrm{c}}$ & 100 & 60 & 70 \\
\hline 9 & 1.5 & - & $\mathrm{TFE}^{\mathrm{c}}$ & 100 & 60 & 56 \\
\hline 10 & 1.5 & - & $\mathrm{TFE}^{\mathrm{c}}$ & 100 & 90 & 61 \\
\hline
\end{tabular}

Isolated yields; ${ }^{\mathrm{b}}$ complex mixture of products; ${ }^{\mathrm{c}}$ 2,2,2-trifluoroethanol.

Bode and Kaye ${ }^{11,22}$ to indolizine-2-carbonitrile (1) and methyl indolizine-2-carboxylate (2) formation.

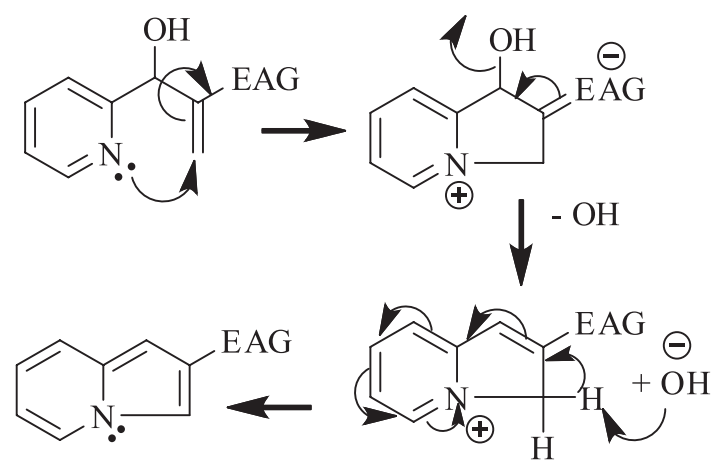

Scheme 6. Proposed mechanism of indolizine-2-carbonitrile (1) and methyl indolizine-2-carboxylate (2) formation. EAG = electron-attractorgroup; $\mathrm{CN}$ or $\mathrm{CO}_{2} \mathrm{CH}_{3}{ }^{22}$

Indolizin-2-yl-methanamine synthesis (4) was performed by indolizine-2-carbonitrile (1) with $\mathrm{LiAlH}_{4}$ reduction, stirring for $2 \mathrm{~h}$ at $0{ }^{\circ} \mathrm{C}$ in dry THF, producing 4 in $98.5 \%$ (Scheme 5). Curiously, it is oversized in the literature that the amine $\mathbf{4}$ is unstable and cannot be stored efficiently. ${ }^{19}$ However, in our study, compound $\mathbf{4}$ proved to be easily manipulated at room temperature and could be used in the next reaction after several days. It is encouraging us once $\mathbf{4}$ showed the highest in silico score value as ion channel modulator at Molinspiration Cheminformatics program (Table 1).

\section{Conclusion}

It was discovered an efficient route to prepare indolizine2-carbonitrile (1) from MBHA, (microwave irradiation, one-step, $70 \%$ ) two times better than the described synthesis. ${ }^{11}$ Beside this, an efficient one-step procedure to indolizine2-carboxylate (2) (microwave irradiation, $81 \%$ versus two steps, $70 \%$, by conventional heating ${ }^{11}$ was also described here. These two compounds were used to prepare in high yields three compounds described in Figure 3. Syntheses of carboxylic acid (3), alcohol (5) and amine (4) were performed in high yields in a chemoselective way. It was also presented here a strategy based on Molinspiration Cheminformatics program to select compounds with potential biological activities as ion channel modulators. The biological studies 
of these compounds as antihypertensive and anticancer drugs are now in evaluation.

\section{Experimental}

General

All commercially available reagents and solvent were obtained from Sigma-Aldrich ${ }^{\circledR}$ and used without further purification. Reactions were monitored by thin layer chromatography (TLC) using silica gel 60 UV254 Macherey-Nagel pre-coated silica gel plates; the detection was made by a UV lamp. Flash column chromatography was performed on 300-400 mesh silica gel. Organic layers were dried over anhydrous $\mathrm{MgSO}_{4}$ or $\mathrm{Na}_{2} \mathrm{SO}_{4}$ prior to evaporation on a rotary evaporator. Reactions requiring microwave irradiation were performed in a microwave reactor $\mathrm{CEM}^{\circledR}$ model system Discover BenchMate with temperature monitored by built-in infrared sensor. ${ }^{1} \mathrm{H}$ and ${ }^{13} \mathrm{C}$ nuclear magnetic resonance (NMR) spectra were recorded using Varian Mercury Spectra AC 20 spectrometer (200 and $50 \mathrm{MHz}$ for ${ }^{1} \mathrm{H}$ and ${ }^{13} \mathrm{C}$, respectively). Chemical shifts were reported relative to internal tetramethylsilane ( $\delta 0.00 \mathrm{ppm}$ ) for ${ }^{1} \mathrm{H}$, using $\mathrm{CHCl}_{3}-d, \mathrm{CH}_{3} \mathrm{OH}-d_{4}$ or DMSO- $d_{6}$ as solvents. Fourier transform infrared (FTIR) spectra were recorded on a Shimadzu spectrophotometer model IRPrestige-21 in KBr pellets. Gas chromatographymass spectrometry (GC-MS) data were measured with a Shimadzu GCMS-QP2010 mass spectrometer.

Methyl 2-[hydroxyl(2-pyridinyl)methyl] acrylate $(6)^{14}$

Carboxy-2-pyridine (110 mg, $1.0 \mathrm{mmol})$, excess of methyl acrylate $(2 \mathrm{~mL})$ and DABCO $(112 \mathrm{mg}, 1.0 \mathrm{mmol})$ preparation were placed in a $25 \mathrm{~mL}$ flask at $0{ }^{\circ} \mathrm{C}$ under stirrer for $5 \mathrm{~h}$. After that, the reaction medium was directly filtered through silica gel, using hexane/ethyl acetate (7:3) as solvent and the reaction products were concentrated under reduced pressure, producing $100 \%$ of pure methyl 2-[hydroxyl(2-pyridinyl)methyl] acrylate (6).

\section{2-[Hydroxy(pyridine-2-yl)methyl] acrylonitrile $(7)^{14}$}

Carboxy-2-pyridine (110 mg, $1.0 \mathrm{mmol})$, excesses of acrylonitrile $(2 \mathrm{~mL})$ and DABCO (112 mg, $1.5 \mathrm{mmol})$ preparation were placed in a $25 \mathrm{~mL}$ flask at $0{ }^{\circ} \mathrm{C}$ under stirrer for $30 \mathrm{~min}$. After that, the reaction medium was directly filtered through silica gel, using hexane/ethyl acetate $(7: 3)$ as solvent and the reaction products were concentrated under reduced pressure, producing $100 \%$ of pure 2-[hydroxy(pyridine-2-yl)methyl] acrylonitrile (7).
General procedure for the microwave-assisted synthesis of methyl indolizine-2-carbonitrile (1) ${ }^{11}$

The X mmol of 2-[hydroxy(pyridine-2-yl)methyl] acrylonitrile (7) and $\mathrm{Y} \mathrm{mL}$ of solvent were placed in a $10 \mathrm{~mL}$ glass microwave tube with magnetic stirrer at $80{ }^{\circ} \mathrm{C}$ (temperature monitored by built-in infrared sensor) for 20-100 min (Table 3). After the complete reaction, the mixture was brought to room temperature and was directly filtered through silica gel, using hexane/ethyl acetate $(7: 3)$ as solvent and the reaction product was concentrated under reduced pressure producing methyl indolizine2-carboxylate (1) in Z yield (Table 3 ).

General procedure for the microwave-assisted synthesis of methyl indolizine-2-carboxylate (2) ${ }^{11}$

The X mmol of methyl 2-[hydroxyl(2-pyridinyl) methyl] acrylate (6) and $\mathrm{Y} \mathrm{mL}$ of solvent were placed in a $10 \mathrm{~mL}$ glass microwave tube with magnetic stirrer at $80^{\circ} \mathrm{C}$ (temperature monitored by built-in infrared sensor) for 20-100 min (see Table 3). After the complete reaction, the mixture was brought to room temperature and was directly filtered through silica gel, using hexane/ethyl acetate (7:3) as solvent and the reaction product was concentrated under reduced pressure producing methyl indolizine2-carboxylate (2) in Z yield (see Table 2).

Indolizine-2-carboxylic acid (3) preparation ${ }^{20}$

Indolizine-2-carboxylate (2) and $21 \mathrm{~mL}$ of $1 \mathrm{~mol} \mathrm{~L}^{-1}$ $\mathrm{KOH}$ ethanolic solution were placed in a $50 \mathrm{~mL}$ glass round bottom flask. This mixture was refluxing by $16 \mathrm{~h}$. After the end of reaction (verified by TLC), the reaction mixture (dispersion) was carried to room temperature followed by water addition (to solubilize the dispersion) and a $\mathrm{HCl}$ solution $\left(1 \mathrm{~mol} \mathrm{~L}^{-1}\right)$ to obtain $\mathrm{pH} 2-3$. The product was extracted by the organic phase $(3 \times 20 \mathrm{~mL}$ EtOAC $)$, which, in turn, was dried with sodium sulfate anhydrous $\mathrm{Na}_{2} \mathrm{SO}_{4}$ and concentrated under reduced pressure in which it was obtained $\mathbf{3}$ on $100 \%$ isolated yield.

Indolizin-2-ylmethanamine (4) preparation $^{19}$

In a $25 \mathrm{~mL}$ glass round bottom flask, it was placed $1 \mathrm{mmol}$ of indolizine-2-carboxynitrile (1), $2 \mathrm{~mL}$ of dry THF. 3.0 equiv. of $\mathrm{LiAlH}_{4}$ was gradually added in small portions at $0{ }^{\circ} \mathrm{C}$. After that, reaction was stirred for $3 \mathrm{~h}$ at room temperature, followed by slow addition of saturated ammonium hydroxide solution $(0.2 \mathrm{~mL})$. Excess THF was removed by evaporation, followed by partition between 
$25 \mathrm{~mL}$ water and $3 \times 20 \mathrm{~mL}$ dichloromethane, which, in turn, organic phase was dried with sodium sulfate anhydrous $\mathrm{Na}_{2} \mathrm{SO}_{4}$ and concentrated under reduced pressure in which it was obtained $\mathbf{4}$ in $98.5 \%$ isolated yield.

\section{Indolizin-2-ylmethanol (5) preparation ${ }^{19}$}

In a $25 \mathrm{~mL}$ glass round bottom flask, it was placed $1 \mathrm{mmol}$ of indolizine-2-carboxylate (2), $2 \mathrm{~mL}$ of dry THF. 2.0 equiv. of $\mathrm{LiAlH}_{4}$ were gradually added in small portions at $0{ }^{\circ} \mathrm{C}$. After that, reaction was stirred for $3 \mathrm{~h}$ at room temperature, followed by slow addition of saturated ammonium hydroxide solution $(0.2 \mathrm{~mL})$. Excess THF was removed by evaporation, followed by partition between $25 \mathrm{~mL}$ water and $3 \times 20 \mathrm{~mL}$ dichloromethane, which, in turn, was dried with sodium sulfate anhydrous $\mathrm{Na}_{2} \mathrm{SO}_{4}$ and concentrated under reduced pressure where 5 was obtained in $100 \%$ isolated yield.

\section{Supplementary Information}

Supplementary data, spectra and chromatograms are available free of charge at http://jbcs.sbq.org.br as a PDF file.

\section{Acknowledgments}

This work has been supported by Conselho Nacional de Desenvolvimento Científico e Tecnológico (CNPq) and Coordenação de Aperfeiçoamento de Pessoal de Nível Superior (CAPES).

\section{References}

1. Singh, G. S.; Mmatli, E. E.; Eur. J. Med. Chem. 2011, 46, 5237; Zhu, L.; Vimolratana, M.; Brown, S. P.; Medina, J. C.; Tetrahedron Lett. 2008, 49, 1768.

2. Gupta, S. P.; Mathur, A. N.; Nagappa, A. N.; Kumar, D.; Kumaran, S. Eur. J. Med. Chem. 2003, 38, 867.

3. Hutchinson, J. H.; Therien, M.; Frenette, R.; Eur. Pat. Appl. EP542355, 1993.

4. Basavaiah, D.; Reddy, B. S.; Badsara, S. S.; Chem. Rev. 2010, 110, 5447.

5. Gmeiner, P.; Huebner, H.; Bettinetti, L.; Schlotter; PCT Int. Appl. WO 015737, 2006

6. Orme, M. W.; Sawyer, J. S.; Schultze; PCT Int. Appl. WO 000657, 2002.

7. Vemula,V. R.; Vurukonda, S.; Bairi, C. K.; Int. J. Pharm. Sci. Rev. Res. 2011, 11, 159.
8. Gundersen, L.-L.; Malterud, K. E.; Negussie, A. H.; Rise, F.; Teklu, S.; Østby, O. B.; Bioorg. Med. Chem. 2003, 11, 5409; Doering, C. J.; Zamponi, G. W.; J. Bioenerg. Biomembr. 2003, 35, 491; Gupta, S. P.; Mathur, A. N.; Nagappa, A. N.; Kumar, D.; Kumaran, S.; Eur. J. Med. Chem. 2003, 38, 867; Kitadokoro, K.; Hagishita, S.; Sato, T.; Ohtani, M., Miki, K.; J. Biochem. 1998, 123, 619; Elst, L. V.; Chatelain, P.; Manning, A. S.; Larvel, R.; Haverbeke, Y. V.; Muller, R. N.; Eur. J. Pharm. 1994, 251, 163.

9. Paulis, L.; Steckelings, U. M.; Unger; T.; Nat. Rev. Cardiol. 2012, 9, 276.

10. Mao, Z.; Li, X.; Lin, X.; Ping, L.; Wang, Y.; Tetrahedron 2012 , 68, 85; Yan, B.; Zhou, Y.; Zhang, H.; Chen, J.; Liu, Y.; J. Org. Chem. 2007, 72, 7783.

11. Bode, M. L.; Kaye, P. T.; J. Chem. Soc., Perkin Trans. I 1993, 1809.

12. Sousa, S. C. O.; Lima-Junior, C. G.; Silva, F. P. L.; Andrade, N. G.; Barbosa, T. P.; Vasconcellos, M. L. A. A.; J. Braz. Chem. Soc. 2011, 22, 1634.

13. Morita, K.; Suzuki, Z.; Hirose, H.; Bull. Chem. Soc. Jpn. 1968, 41, 2815; Baylis, A. B.; Hillman, M. E. D.; U.S. Patent 3,743,669, 1973 (CA 77:197234174q); Basavaiah, D.; Rao, A. J.; Satyanarayana, T. T.; Chem. Rev. 2003, 103, 811; Basavaiah, D.; Reddy, B. S.; Badsara, S. S.; Chem. Rev. 2010, 110, 5447.

14. Coelho, A. L.; Vasconcellos, M. L. A. A.; Simas, A. B. C.; Rabi, J. A.; Costa, P. R. R.; Synthesis 1992, 914; Cabral, L. M.; Costa, P. R. R.;Vasconcellos, M. L. A. A.; Barreiro, E. J.; Castro, R. N.; Synthetic Comm. 1996, 26, 3671; Lima-Junior, C. G.; Silva, F. P. L.; de Oliveira, R. G.; Subrinho, F. L.; Vasconcellos, M. L. A. A.; J. Braz. Chem Soc. 2011, 22, 2220.

15. Score values have been calculated based on Molinspiration program predictions, http://www.molinspiration.com/cgi-bin/ properties accessed in June 2012.

16. Lipinski, C. A.; Lombardo, F.; Dominy, B. W.; Feeney, P. J; Adv. Drug Delivery Rev. 2001, 46, 3.

17. Duarte, C. D.; Barreiro, E. J.; Fraga, C. A. M.; Mini-Rev. Med. Chem. 2007, 7, 1108.

18. http://www.molinspiration.com/papers/index.html accessed in April 2012.

19. Jones, G.; Stanyer, J.; J. Chem. Soc. C 1969, 901.

20. Bode, M. L.; Kaye, P. T.; Rosemary, G.; J. Chem. Soc., Perkin Trans. 1 1994, 3023.

21. de Paiva, Y. G.; de Souza, A. A.; Lima-Junior, C. G.; Silva, F. P. L.; Filho, E. B. A.; de Vasconcelos, C. C.; de Abreu, F. C.; Goulart, M. O. F.; Vasconcellos, M. L. A. A.; J. Braz. Chem. Soc. 2012, 23, 894.

22. Bode, M. L.; Kaye, P. T.; J. Chem. Soc., Perkin Trans. 11990 , 2612.

Submitted: June 29, 2012

Published online: March 12, 2013 